\title{
Attenuation of oxidative stress in U937 cells by polyphenolic-rich bark fractions of Burkea africana and Syzygium cordatum
}

Werner Cordier ${ }^{1}$, Mary Gulumiann ${ }^{2,3}$, Allan Duncan Cromarty ${ }^{1}$ and Vanessa Steenkamp ${ }^{1 *}$

\begin{abstract}
Background: Oxidative stress has been implicated in the progression of various diseases, which may result in the depletion of endogenous antioxidants. Exogenous supplementation with antioxidants could result in increased protection against oxidative stress. As concerns have been raised regarding synthetic antioxidant usage, the identification of alternative treatments is justified. The aim of the present study was to determine the antioxidant efficacy of Burkea africana and Syzygium cordatum bark extracts in an in vitro oxidative stress model.
\end{abstract}

Methods: Cytotoxicity of crude aqueous and methanolic extracts, as well as polyphenolic-rich fractions, was determined in C2C12 myoblasts, 3T3-L1 pre-adipocytes, normal human dermal fibroblasts and U937 macrophagelike cells using the neutral red uptake assay. Polyphenolic content was determined using the Folin-Ciocalteau and aluminium trichloride assays, and antioxidant activity using the Trolox Equivalence Antioxidant Capacity and DPPH assays. The extracts efficacy against oxidative stress in AAPH-exposed U937 cells was assessed with regards to reactive oxygen species generation, cytotoxicity, apoptosis, lipid peroxidation and reduced glutathione depletion.

Results: B. africana and S. cordatum showed enrichment of polyphenols from the aqueous extract, to methanolic extract, to polyphenolic-rich fractions. Antioxidant activity followed the same trend, which correlated well with the increased concentration of polyphenols, and was between two- to three-fold stronger than the Trolox antioxidant control. Both plants had superior activity compared to ascorbic acid in the DPPH assay. Polyphenolic-rich fractions were most toxic to the 3T3-L1 ( $I C_{50}$ 's between 13 and $21 \mu \mathrm{g} / \mathrm{ml}$ ) and $\mathrm{C} 2 \mathrm{C} 12\left(\mathrm{IC}_{50}{ }^{\prime} \mathrm{s}\right.$ approximately $\left.25 \mu \mathrm{g} / \mathrm{ml}\right)$ cell lines, but were not cytotoxic in the U937 and normal human dermal fibroblasts cultures. Free radical-induced generation of reactive oxygen species (up to 80\%), cytotoxicity (up to 20\%), lipid peroxidation (up to 200\%) and apoptosis (up to 60\%) was successfully reduced by crude extracts of B. africana and the polyphenolic-rich fractions of both plants. The crude extracts of S. cordatum were not as effective in reducing cytotoxic parameters.

Conclusion: Although oxidative stress was attenuated in U937 cells, cytotoxicity was observed in the 3T3-L1 and C2C12 cell lines. Further isolation and purification of polyphenolic-fractions could increase the potential use of these extracts as supplements by decreasing cytotoxicity and maintaining antioxidant quality.

Keywords: Antioxidant, Apoptosis, Burkea africana, Cytotoxicity, Free radicals, Glutathione, Lipid peroxidation, Oxidative stress, Polyphenols, Syzygium cordatum

\footnotetext{
* Correspondence: vanessa.steenkamp@up.ac.za

'Department of Pharmacology, Faculty of Health Sciences, School of

Medicine, University of Pretoria, P.O. Box X323, Arcadia 0007, Pretoria, South

Africa

Full list of author information is available at the end of the article
} 


\section{Background}

Worldwide there is a high burden of disease, including diabetes mellitus, cardiomyopathy, nephropathy, cancer and neurodegenerative disorders [1,2]. Although reactive oxygen species (ROS) are formed during normal cellular functioning, high concentrations result in a period of oxidative stress [1]. During oxidative stress the human body is not able to maintain a homeostasis between endogenous antioxidants and ROS [1-3], with subsequent oxidationinduced damage to biomolecules. Damage incurred may present itself as apoptosis, lipid peroxidation, DNA degradation, protein modification, inflammation and ultimately cellular death [3], which may aggravate oxidative stress-related disorders [4].

Antioxidants are molecules that decrease the propagation and activity of free radicals through neutralization and quenching reactions [2]. Endogenous antioxidants, including enzymes (such as superoxide dismutase) and molecules (such as reduced glutathione [GSH]), aim to maintain homeostasis and reduce the deleterious effects of oxidative stress [2,3]. GSH is a non-protein thiol present at high levels in healthy cells, while the oxidized form (GSSG) appears at insignificant concentrations [5]. High concentrations of ROS can result in the depletion of GSH. During such periods the need for exogenous antioxidants becomes apparent. Due to controversies surrounding the potential cytotoxicity and carcinogenicity of synthetic antioxidants, novel antioxidant sources such as herbal remedies are therefore actively being investigated [6].

Plants are known to be rich antioxidant sources $[7,8]$. Burkea africana Hook.F (Fabaceae) and Syzygium cordatum Hochst. Ex C. Krauss (Myrtaceae) are two African plants that have been described in literature to contain high levels of polyphenols and antioxidants in their bark extracts $[7,8]$. The former, otherwise commonly known as the wild seringa, is used to treat heavy menstruation, abdominal pain, inflammation and pneumonia [7], while the latter, otherwise known as the waterberry, is used ethnomedicinally as an emetic, treatment of diarrhea, stomach aches and chest complaints [8].

The aim of the present study was therefore to investigate the polyphenolic content of the bark extracts of B. africana and S. cordatum, assess their antioxidant activity and/or cytotoxicity, as well as their efficacy to protect against oxidative stress in an in vitro cellular model, with the hope of determining their suitability of use as supplementary antioxidants.

\section{Methods}

\section{Plant material and extract preparation} Plant material

Bark of B. africana and S. cordatum were collected during Spring (September) by Mr Lawrence Tshikhudo in Venda and Dr N Hahn in Machado (Limpopo), res- pectively. The identity of the plants was confirmed by Dr Hahn and voucher specimens deposited at the Department of Toxicology (B. africana, LT15) (Onderstepoort Veterinary Institute, Pretoria, South Africa) and the Soutpansbergensis Herbarium, Makado (S. cordatum, NH1880). Bark was cleaned, air-dried and ground to a fine powder (YellowLine Grinder, Merck).

\section{Preparation of crude extracts}

Bark powder (50 g) was macerated in $500 \mathrm{ml}$ distilled water or methanol, sonicated for $30 \mathrm{~min}$ and kept at $4{ }^{\circ} \mathrm{C}$ for $24 \mathrm{~h}$. The supernatant was stored, and the marc extracted for a second time following the same method. The respective extracts were combined and vacuum-filtered $(0.22 \mu \mathrm{m})$. Aqueous and methanolic extracts were concentrated through in vacuo lyophilization (Freezone 6 Freeze Dry System, Labconco) or rotary-evaporation (Büchi Rotovapor R-200, Büchi), respectively. Methanolic extracts were reconstituted in absolute ethanol to a $100 \mathrm{mg} / \mathrm{ml}$ stock. All extracts were dissolved prior to use to the desired concentrations (serial dilutions from $1 \mathrm{mg} / \mathrm{ml}$ ) in phosphate buffered saline (PBS) and stored at $-20^{\circ} \mathrm{C}$.

\section{Preparation of polyphenolic-rich fractions}

Polyphenolic-rich fractions were prepared according to the method of Jung et al. [9]. Bark powder (50 g) was defatted twice for $2 \mathrm{~h}$ with $80 \mathrm{ml}$ hexane on a mechanical shaker. The hexane solvent was discarded, the defatted bark powder was air-dried and macerated in $200 \mathrm{ml}$ methanol:acetone:water $(80: 15: 5)$ at $4^{\circ} \mathrm{C}$ for $24 \mathrm{~h}$. The extract was then vacuum-filtered $(0.22 \mu \mathrm{m})$ and concentrated through in vacuo rotary-evaporation to $10 \mathrm{ml}$. Thereafter, the extract was mixed with $100 \mathrm{ml}$ acidified

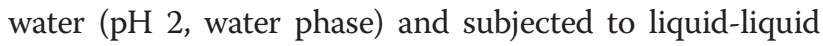
extraction (five times) for $1 \mathrm{~h}$ using $100 \mathrm{ml}$ diethyl etherethyl acetate (1:1, DE/EA, organic phase). The organic phase was stored at $-20^{\circ} \mathrm{C}$ until use.

The water phase was neutralized to $\mathrm{pH} 7$ using $2 \mathrm{M}$ sodium hydroxide, lyophilized and hydrolyzed with $100 \mathrm{ml}$ $2 \mathrm{M}$ sodium hydroxide for $4 \mathrm{~h}$ on a mechanical shaker at room temperature. The solution was then acidified to $\mathrm{pH} 2$ with $6 \mathrm{M}$ hydrochloric acid, and again subjected to liquid-liquid extraction as described above. The organic phases were combined, dehydrated with anhydrous sodium sulphate, vacuum-filtered $(0.22 \mu \mathrm{m})$ and evaporated to dryness through in vacuo rotary-evaporation to form the polyphenolic-rich fraction. The evaporated fraction was dissolved in absolute ethanol to $100 \mathrm{mg} / \mathrm{ml}$, dissolved to desired concentrations (serial dilutions from $1 \mathrm{mg} / \mathrm{ml}$ ) in $\mathrm{PBS}$ and aliquots stored at $-20^{\circ} \mathrm{C}$ until use.

\section{Phytochemical screening}

Phytochemical screening of crude extracts and polyphenolicrich fractions for alkaloids, ascorbic acid, coumarins, specific 
flavonoids (apigenin, catechin, daidzein, epigallocatechin, genistein, hesperidin, kaempferol, myricetin, quercetin, rutin, sinapic acid and vitexin) and phenolic acids (benzoic acid, caffeic acid, ferulic acid, gallic acid, p-coumaric acidand syringic acid) were performed using thin-layer chromatography (TLC) [10]. The presence of glycosides, terpenoids and steroids was determined using biochemical reactions [11]. Glycoside presence was identified by a red-brown reaction upon treatment with sulphuric acid and ferric chloride. Terpenoid and steroid presence was determined using sulphuric acid, where a red-violet and green-blue reaction was a positive indication, respectively.

\section{Determination of total polyphenolic content (phenolic acids and flavonoids) \\ Total phenolic content (TPC)}

The TPC of the crude extracts and polyphenolic-rich fractions was determined using the Folin-Ciocalteu assay as described by Slinkard \& Singleton [12]. A standard curve was prepared using gallic acid. Into a tube was pipetted: $75 \mu \mathrm{l}$ gallic acid standards (half serial dilutions of $1 \mathrm{mg} / \mathrm{ml}$ ), crude extract, or polyphenolic-rich fraction, as well as $5925 \mu$ l distilled water and $375 \mu$ l FolinCiocalteu reagent. Tubes were incubated for $8 \mathrm{~min}$ after which $1125 \mu$ l sodium carbonate solution (20\%) was added. Tubes were agitated and incubated in the dark for $2 \mathrm{~h}$. Absorbance was measured at $765 \mathrm{~nm}$ (Lambda 25 UV/VIS Spectrophotometer, Perkin Elmer). Results are expressed as gallic acid equivalents (GAE mg/g extract \pm SEM) which were calculated using the following equation:

$$
G A E=\frac{c \times v \times D F}{m}
$$

where, $\mathrm{c}=$ concentration calculated from standard curve (in $\mathrm{mg} / \mathrm{ml}$ ); $\mathrm{v}=$ volume obtained from initial extraction of plant material (in $\mathrm{ml}$ ); $\mathrm{DF}=$ dilution factor of sample; and $\mathrm{m}=$ total weight of extract (in $\mathrm{g}$ ).

\section{Total flavonoid content (TFC)}

The TFC of the crude extracts and polyphenolic-rich fractions was determined using the aluminium trichloride assay as described by Dewanto et al. [13]. A standard curve was prepared using rutin hydrate. Into a 96-well plate was pipetted: $20 \mu \mathrm{l}$ rutin hydrate standard (half serial dilutions of $1 \mathrm{mg} / \mathrm{ml}$ ), crude extract, or polyphenolic-rich fraction, as well as $20 \mu \mathrm{l}$ sodium nitrate solution (3\%), $20 \mu \mathrm{l}$ aluminum trichloride solution $(1 \%)$ and $100 \mu \mathrm{l}$ sodium hydroxide solution $(0.5 \mathrm{M})$. Absorbance was measured at $570 \mathrm{~nm}$ (ELx800 Universal Microplate Reader, Bio-Tek Instruments, Inc.). Results are expressed as rutin equivalents (RE $\mathrm{mg} / \mathrm{g}$ extract $\pm \mathrm{SEM})$ which were calculated using the following equation:

$$
R E=\frac{c \times v \times D F}{m}
$$

where, $\mathrm{c}=$ concentration calculated from standard curve (in $\mathrm{mg} / \mathrm{ml}$ ); $\mathrm{v}=$ volume obtained from initial extraction of plant material (in $\mathrm{ml}$ ); $\mathrm{DF}=$ dilution factor of sample; and $\mathrm{m}=$ total weight of extract (in $\mathrm{g}$ ).

\section{Determination of cell-free antioxidant activity}

\section{Trolox equivalence antioxidant capacity (TEAC) assay}

The 2,2'-azino-bis-(3-ethyl benzothiazoline 6-sulfonic acid) radical $\mathrm{ABTS}^{\cdot+}$ scavenging activity of crude extracts and polyphenolic-rich fractions were determined using the TEAC assay as described by Re et al. [14]. Aqueous $\mathrm{ABTS}^{*+}(7.46 \mathrm{mM})$ was prepared in distilled water and oxidized using $2.5 \mathrm{mM}$ potassium peroxidisulfate at $4^{\circ} \mathrm{C}$ for $16 \mathrm{~h} . \mathrm{ABTS}^{\circ+}$ was diluted with distilled water to an absorbance of $0.70 \pm 0.02$ absorbance units at $734 \mathrm{~nm}$. A standard curve was prepared using Trolox (half serial dilutions of $1 \mathrm{mg} / \mathrm{ml}$ ) and samples were tested at four different concentrations $(0.05$ to $0.6 \mathrm{mg} / \mathrm{ml})$. Into a cuvette was pipetted: $20 \mu \mathrm{l}$ Trolox standard, crude extract, polyphenolic-rich fraction or ascorbic acid (as antioxidant control) as well as $2 \mathrm{ml} \mathrm{ABTS}^{*+}$. Absorbance was measured at $734 \mathrm{~nm}$ after $1 \mathrm{~min}$ incubation. Results are expressed as Trolox equivalents (TE ratio \pm SEM) which were calculated using the following equation:

$$
T E=\frac{\operatorname{slope}(T)}{\operatorname{slope}(S)}
$$

where, slope $(\mathrm{T})=$ slope of Trolox standards curve; slope $(\mathrm{S})=$ slope of sample curve.

\section{1,1-diphenyl-2-picrylhydrazyl (DPPH) radical assay}

The DPPH radical scavenging activity of crude extracts and polyphenolic-rich fractions were determined using the DPPH assay as described by Gyamfi et al. [15]. A standard curve was prepared using Trolox (half serial dilutions of $0.5 \mathrm{mg} / \mathrm{ml}$ ) and samples were tested at four different concentrations $(0.05$ to $0.6 \mathrm{mg} / \mathrm{ml})$. Into a 96-well plate was pipetted: $15 \mu \mathrm{l}$ Trolox standard, crude extract, polyphenolic-rich fraction or ascorbic acid as well as $185 \mu \mathrm{D}$ DPPH solution $(240 \mu \mathrm{M})$. Absorbance was measured after $15 \mathrm{~min}$ at $570 \mathrm{~nm}$. Results are expressed as TE (ratio \pm SEM) using the equation in Section Trolox equivalence antioxidant capacity (TEAC) assay.

\section{Cytotoxicity}

\section{Culture, maintenance and seeding of cells}

Normal human dermal fibroblasts (NHDF) were purchased from Southern Medical (South Africa), while 
3T3-L1 murine pre-adipocyte (\#CL-173) and C2C12 murine myoblast (\#CRL-1722) cell lines were purchased from the American Type Culture Collection. Adherent NHDF, 3T3-L1 and C2C12 cells were cultured in $10 \%$ foetal calf serum-supplemented Dulbecco's Modified Eagle Medium (DMEM) with penicillin (100 U/ml) and streptomycin $(100 \mu \mathrm{g} / \mathrm{ml})$ at $37^{\circ} \mathrm{C}$ and $5 \% \mathrm{CO}_{2}$. Once cells became confluent, flasks were rinsed with PBS and cells enzymatically detached with Trypsin/Versene solution for 5 to $10 \mathrm{~min}$. Cells were washed $(200 \mathrm{~g}$, $5 \mathrm{~min}$ ) (TJ-6 Centrifuge, Beckman) and resuspended to $5 \times 10^{4}$ cells $/ \mathrm{ml}$ in $2 \%$ FCS-supplemented DMEM after determination of viability using the trypan blue exclusion assay (MicroStar 110, Reichert-Jung) and a haemocytometer.

The U937 human pro-monocytic cell line was obtained from European Collection of Cell Cultures (Sigma). Non-adherent U937 cells were cultured in 10\% FCS-supplemented Roswell Park Memorial Institution (RPMI)-1640 with penicillin $(100 \mathrm{U} / \mathrm{ml})$ and streptomycin $(100 \mu \mathrm{g} / \mathrm{ml})$ at $37^{\circ} \mathrm{C}$ and $5 \% \mathrm{CO}_{2}$. Cells were washed ( $200 \mathrm{~g}, 5 \mathrm{~min}$ ), counted using the trypan blue exclusion assay and diluted to $1 \times 10^{6}$ cells $/ \mathrm{ml}$ in $10 \%$ FCS-supplemented RPMI-1640. Cells were differentiated for $48 \mathrm{~h}$ with $32 \mathrm{nM}$ phorbol-12-myristate-13-acetate (PMA) at $37^{\circ} \mathrm{C}$ and $5 \% \mathrm{CO}_{2}$. Cells were harvested and recounted using the trypan blue exclusion assay after differentiation and diluted to $1 \times 10^{6}$ cells $/ \mathrm{ml}$ in $2 \%$ FCS-supplemented RPMI-1640.

Into a 96-well plate was pipetted: a $100 \mu \mathrm{l}$ cell suspension $\left(5 \times 10^{3}\right.$ cells/well and $1 \times 10^{5}$ cells/well for adherent and non-adherent cells, respectively) and $80 \mu \mathrm{l} 2 \%$ FCS-supplemented medium. Plates were incubated at $37^{\circ} \mathrm{C}$ and $5 \% \mathrm{CO}_{2}$ for $1 \mathrm{~h}$ or $24 \mathrm{~h}$ for non-adherent or adherent cell lines, respectively.

\section{Cytotoxicity of crude extracts and polyphenolic-rich fractions}

Cytotoxicity was determined using the neutral red uptake assay as described by Borenfreund et al. [16]. The final concentration of ethanol used in the cellular assays for the methanolic extract and polyphenolic-rich fraction did not exceed $0.1 \%$. The cytotoxicity of crude extracts and polyphenolic rich samples was determined in preseeded plates by addition of $20 \mu \mathrm{l}$ medium (negative control), crude extracts or polyphenolic-rich fractions $(0.0078 \mathrm{mg} / \mathrm{ml}$ to $1 \mathrm{mg} / \mathrm{ml})$ and incubation for $72 \mathrm{~h}$ at $37^{\circ} \mathrm{C}$ and $5 \% \mathrm{CO}_{2}$. Medium was replaced with $100 \mu \mathrm{l}$ neutral red medium $(200 \mu \mathrm{g} / \mathrm{ml})$ and incubated for $3 \mathrm{~h}$ after which plates were washed with PBS ( $200 \mathrm{~g}, 5 \mathrm{~min})$. Plates were left to dry, the dye dissolved using $100 \mu \mathrm{l}$ neutral red eluent (ethanol:distilled water:acetic acid [49:50:1]) and the absorbance measured at $540 \mathrm{~nm}$ (and blanked to the reference wavelength, $630 \mathrm{~nm}$ ).

\section{Attenuation of oxidative stress-induced parameters in U937 cells}

The oxidant 2,2'-azobis-(2-methylpropionamidine) dihydrochloride (AAPH) is able to generate free radicals such as hydroxyls during thermolysis reactions [17,18]. During generation of ROS, cells undergo cytotoxicity that can be detected as GSH depletion, apoptosis and lipid peroxidation. These parameters can be measured using fluorometric and spectrophotometric assays.

\section{Induction of $A A P H$-induced oxidative stress}

Into pre-seeded U937 plates was pipetted: $20 \mu \mathrm{l}$ medium (negative control), positive control (see respective sections), crude extract, polyphenolic-rich fraction $(25,50$, 100 and $200 \mu \mathrm{g} / \mathrm{ml}$ ) or $10 \mathrm{mM}$ Trolox (as antioxidant comparison) and incubated for $1 \mathrm{~h}$ at $37^{\circ} \mathrm{C}$ and $5 \% \mathrm{CO}_{2}$. In all experiments, except the ROS generation assays described in Section Efficacy to protect against AAPHinduced ROS generation, plates were washed with RPMI-1640 (200 g, $5 \mathrm{~min}$ ), treated with $1.5 \mathrm{mM} \mathrm{AAPH}$ (final reaction volume $200 \mu \mathrm{l}$ ) and incubated for $48 \mathrm{~h}$ at $37^{\circ} \mathrm{C}$ and $5 \% \mathrm{CO}_{2}$.

All values were adjusted by subtraction of the blank. The results for percentage viability, apoptosis, lipid peroxidation and GSH depletion were expressed relative to the negative control using the following equation:

$$
\operatorname{Parameter}(\%)=\frac{A(\text { sample })}{A(\text { control })} \times 100
$$

where, $\mathrm{A}($ control $)=$ intensity of triplicate negative control; $\mathrm{A}($ sample $)=$ triplicate intensity of sample at a given concentration.

\section{Efficacy to protect against $A A P H$-induced cytotoxicity}

The ability of crude extracts and polyphenolic-rich fractions to attenuate AAPH-induced cytotoxicity in preseeded U937 plates was measured using the neutral red uptake assay as described in Section Cytotoxicity of crude extracts and polyphenolic-rich fractions. Saponin (1\%) was used as positive control.

\section{Efficacy to protect against $A A P H$-induced ROS generation}

The ability of crude extracts and polyphenolic-rich fractions to attenuate AAPH-induced ROS generation was measured using the 2', 7'-dichlorodihydrofluorescein diacetate (DCFHDA) method as described by Jakubowski and Bartosz [19]. Into pre-seeded U937 white plates was pipetted: a $20 \mu \mathrm{l}$ medium, crude extract, polyphenolic-rich fraction $(2.5,5,10$ and $20 \mu \mathrm{g} / \mathrm{ml}$ ) or $1 \mathrm{mM}$ Trolox and $5 \mu \mathrm{M}$ DCFHDA, which was incubated for $1 \mathrm{~h}$ at $37^{\circ} \mathrm{C}$ and $5 \% \mathrm{CO}_{2}$. Plates were washed with PBS (200 g, $5 \mathrm{~min}$ ) and treated with $1.5 \mathrm{mM}$ AAPH (final reaction volume $200 \mu \mathrm{l}$ ). Fluorescence was measured over a period of $3 \mathrm{~h}$ at $\lambda_{\mathrm{ex}}=485 \mathrm{~nm}$ and $\lambda_{\mathrm{em}}=520 \mathrm{~nm}$ 
(FLUOstar Optima, BMG Labtech). Percentage inhibition was determined using the following equation:

$$
\operatorname{Inhibition}(\%)=\frac{A U C(A A P H)-A U C(\text { sample })}{A U C(A A P H)} \times 100
$$

where, $\mathrm{AUC}(\mathrm{AAPH})=$ average area under curve of $\mathrm{AAPH}$ exposed cells; AUC(sample) = average area under curve of sample-treated, AAPH-exposed cells.

\section{Efficacy to protect against AAPH-induced apoptosis}

The ability of crude extracts and polyphenolic-rich fractions to attenuate AAPH-induced apoptosis was measured using the caspase- 3 activity assay as described by Banjerdpongchai et al. [20]. Staurosporine $(20 \mu \mathrm{M})$ was employed as positive control. Pre-seeded U937 AAPHexposed plates were centrifuged ( $200 \mathrm{~g}$, $5 \mathrm{~min}$ ), medium replaced with $25 \mu \mathrm{l}$ cold lysis buffer and incubated for 15 min on ice. Thereafter, a $100 \mu$ l caspase- 3 substrate buffer containing Ac-DEVD-AMC was added and plates were incubated for $3 \mathrm{~h}$ at $37^{\circ} \mathrm{C}$. Fluorescence was measured at $\lambda_{\mathrm{ex}}=355 \mathrm{~nm}$ and $\lambda_{\mathrm{em}}=460 \mathrm{~nm}$.

\section{Efficacy to protect against AAPH-induced lipid peroxidation}

The ability of crude extracts and polyphenolic-rich fractions to attenuate AAPH-induced lipid peroxidation was measured using the thiobarbituric acid (TBA) assay as described by Stern et al. [21]. Hydrogen peroxide $\left(\mathrm{H}_{2} \mathrm{O}_{2}\right)(20 \mu \mathrm{M})$ was used as positive control. From preseeded U937 AAPH-exposed plates were taken aliquots of supernatant $(150 \mu \mathrm{l})$, which were mixed with $200 \mu \mathrm{l}$ trichloroacetic acid (12.5\%) and $400 \mu \mathrm{l} \mathrm{TBA} \mathrm{(1 \% )} \mathrm{and} \mathrm{in-}$ cubated at $95^{\circ} \mathrm{C}$ for $20 \mathrm{~min}$. 3-Methyl butan-1-ol $(1 \mathrm{ml})$ was added to the mixture, vortex mixed and the organic layer was left to separate from the aqueous layer. Into a white 96-well plate was transferred $100 \mu \mathrm{l}$ of the organic layer and the fluorescence measured at $\lambda_{\mathrm{ex}}=544 \mathrm{~nm}$ and $\lambda_{\mathrm{em}}=590 \mathrm{~nm}$.
Efficacy to protect against AAPH-induced GSH depletion

The ability of crude extracts and polyphenolic-rich fractions to attenuate AAPH-induced GSH depletion was measured using the monochlorobimane assay as described by Fernandez-Checa and Kaplowitz [22]. $\mathrm{H}_{2} \mathrm{O}_{2}$ $(20 \mu \mathrm{M})$ was used as positive control. Into pre-seeded U937 AAPH-exposed plates was pipetted $50 \mu \mathrm{M}$ monochlorobimane and plates were incubated for $1 \mathrm{~h}$. Plates were washed twice with PBS $(200 g, 5 \mathrm{~min})$ after which the fluorescence was measured at $\lambda_{\mathrm{ex}}=355 \mathrm{~nm}$ and $\lambda_{\mathrm{em}}=460 \mathrm{~nm}$.

\section{Statistical analyses}

All experiments were performed in triplicate on three separate days and results expressed as mean \pm SEM using GraphPad Prism 4. The concentration needed to inhibit $50 \%$ of cell viability $\left(\mathrm{IC}_{50}\right)$ was determined through using non-linear regression (variable slope). Results of attenuation of AAPH-induced parameters were compared with each other using one way analysis of variance (ANOVA) with a post-hoc Dunnett's test. Significance was noted as $\mathrm{p}<0.05$.

\section{Results and discussion}

\section{Phytochemical composition}

In the present study alkaloids, flavonoids, glycosides, phenolic acids and terpenoids were identified in all the samples. Coumarins were only detected in the polyphenolic-rich fraction of $S$. cordatum. In the present study, polyphenols such as caffeic acid, cinnamic acid, epigallocatechin, gallic acid and sinapic acid were identified in both plants, while B. africana additionally tested positive for catechin and myricetin, and only S. cordatum for hesperidin. Flavonoids, glycosides, phenolic acids,proanthocyanidins, terpenoids and specific compounds such as catechin, epicatechin and fisetinidol have been described for the bark of $B$. africana in literature $[7,23,24]$. Compounds previously identified in the bark of $S$. cordatum include: alkaloids, flavonoids, phenolic acids (such as gallic acid), glucose,

Table 1 Total polyphenolic content and antioxidant activity of crude extracts and polyphenolic-rich fractions

\begin{tabular}{|c|c|c|c|c|c|}
\hline \multirow[t]{3}{*}{ Plant } & \multirow{3}{*}{$\begin{array}{l}\text { Extract/ } \\
\text { Fraction }\end{array}$} & \multirow{3}{*}{$\begin{array}{l}\text { TPC (GAE } \mathbf{m g} / \mathrm{g} \\
\text { extract } \pm \text { SEM) }\end{array}$} & \multirow{3}{*}{$\begin{array}{l}\text { TFC (RE } \mathrm{mg} / \mathrm{g} \\
\text { extract } \pm \mathrm{SEM})\end{array}$} & \multirow{2}{*}{\multicolumn{2}{|c|}{$\begin{array}{c}\text { Antioxidant activity } \\
(\mathrm{TE} \pm \mathrm{SEM})\end{array}$}} \\
\hline & & & & & \\
\hline & & & & TEAC & DPPH \\
\hline \multirow[t]{3}{*}{ B. africana } & Aqueous & $260.1 \pm 10.8$ & $196.8 \pm 7.3$ & $1.2 \pm 0.0$ & $1.1 \pm 0.0$ \\
\hline & Methanolic & $484.4 \pm 13.7$ & $334.3 \pm 3.0$ & $1.4 \pm 0.0$ & $1.5 \pm 0.0$ \\
\hline & Polyphenolic & $699.1 \pm 25.3$ & $460.0 \pm 18.9$ & $2.0 \pm 0.1$ & $2.2 \pm 0.0$ \\
\hline \multirow[t]{3}{*}{ S. cordatum } & Aqueous & $183.9 \pm 5.6$ & $130.6 \pm 9.5$ & $0.8 \pm 0.0$ & $0.7 \pm 0.0$ \\
\hline & Methanolic & $260.8 \pm 9.2$ & $192.2 \pm 8.9$ & $1.1 \pm 0.0$ & $1.1 \pm 0.0$ \\
\hline & Polyphenolic & $619.4 \pm 11.3$ & $334.0 \pm 9.7$ & $2.5 \pm 0.1$ & $3.0 \pm 0.1$ \\
\hline Ascorbic acid & & - & - & $2.8 \pm 0.0$ & $1.7 \pm 0.0$ \\
\hline
\end{tabular}

GAE, Gallic acid equivalents; TFC, Total flavonoid content; RE, Rutin equivalents; TE, Trolox equivalents. 
Table 2 The cytotoxicity of crude extracts and polyphenolic-rich fractions on different cell line cultures

\begin{tabular}{llcccc}
\hline Plant & Extract/ & \multicolumn{4}{c}{ IC $_{\mathbf{5 0}} \pm$ SEM $(\boldsymbol{\mu g} / \mathbf{m l})$} \\
\cline { 3 - 6 } & Fraction & C2C12 & 3T3-L1 & NHDF & U937 \\
\hline B. africana & Aqueous & $42.5 \pm 1.1$ & $84.5 \pm 1.0$ & $>100$ & $>100$ \\
& Methanolic & $16.0 \pm 1.0$ & $28.5 \pm 1.0$ & $>100$ & $>100$ \\
& Polyphenolic & $13.9 \pm 1.0$ & $24.3 \pm 1.0$ & $>100$ & $>100$ \\
S. cordatum & Aqueous & $63.4 \pm 1.0$ & $31.4 \pm 1.0$ & $>100$ & $>100$ \\
& Methanolic & $95.6 \pm 1.1$ & $74.6 \pm 1.0$ & $>100$ & $>100$ \\
& Polyphenolic & $20.5 \pm 1.1$ & $25.0 \pm 1.0$ & $>100$ & $>100$ \\
\hline
\end{tabular}

proanthocyanidins, a gallic-acid-ellagic acid complex, the leucoanthocyanidins (leucodelphinidin and leucocyanidin), a phytosterol ( $\beta$-sitosterol) and the terpenoids arjunolic acid, friedelin and epi-friedelinol [25-27].

\section{Polyphenolic content and antioxidant activity}

Crude extracts and the polyphenolic-rich fraction of $B$. africana contained approximately 2-fold higher polyphenolic content than S. cordatum (Table 1). Polyphenolic content increased by approximately 1.8 -fold from the aqueous to methanolic extracts in both plants.
A further 1.4-fold and 2-fold increase was seen from methanolic extracts to polyphenolic-rich fractions for $B$. africana and $S$. cordatum, respectively.

The antioxidant activity of the crude extracts of $B$. africana was higher than that of $S$. cordatum, whereas the opposite was seen for the polyphenolic-rich fractions (Table 1). Antioxidant activity could be explained by the presence of polyphenols as a correlation was seen: phenolic content, $r>0.85$; flavonoid content, $r>0.72$. The antioxidant activity was similar between the TEAC and DPPH assays, which could be explained due to the similar mechanism of quenching in both assays. Antioxidant activity of $B$. africana has been reported using the $\beta$-carotene [23] and the DPPH radical scavenging assays $[7,23]$. Previously, antioxidant activity of crude extracts of $S$. cordatum bark was reported to be higher in the aqueous extract (1.95 TE) than the methanolic extract (0.80 TE) [27]. Hydroxyl groups are known to increase radical scavenging activity [28]. Leucocyanidin, leucodelphinidin, catechin, epicatechin, myricetin and proanthocyanidins (all of which have been described in both plants) contain numerous hydroxyl groups. Importantly, both plants had superior activity to ascorbic acid in the DPPH assay, indicating more potent
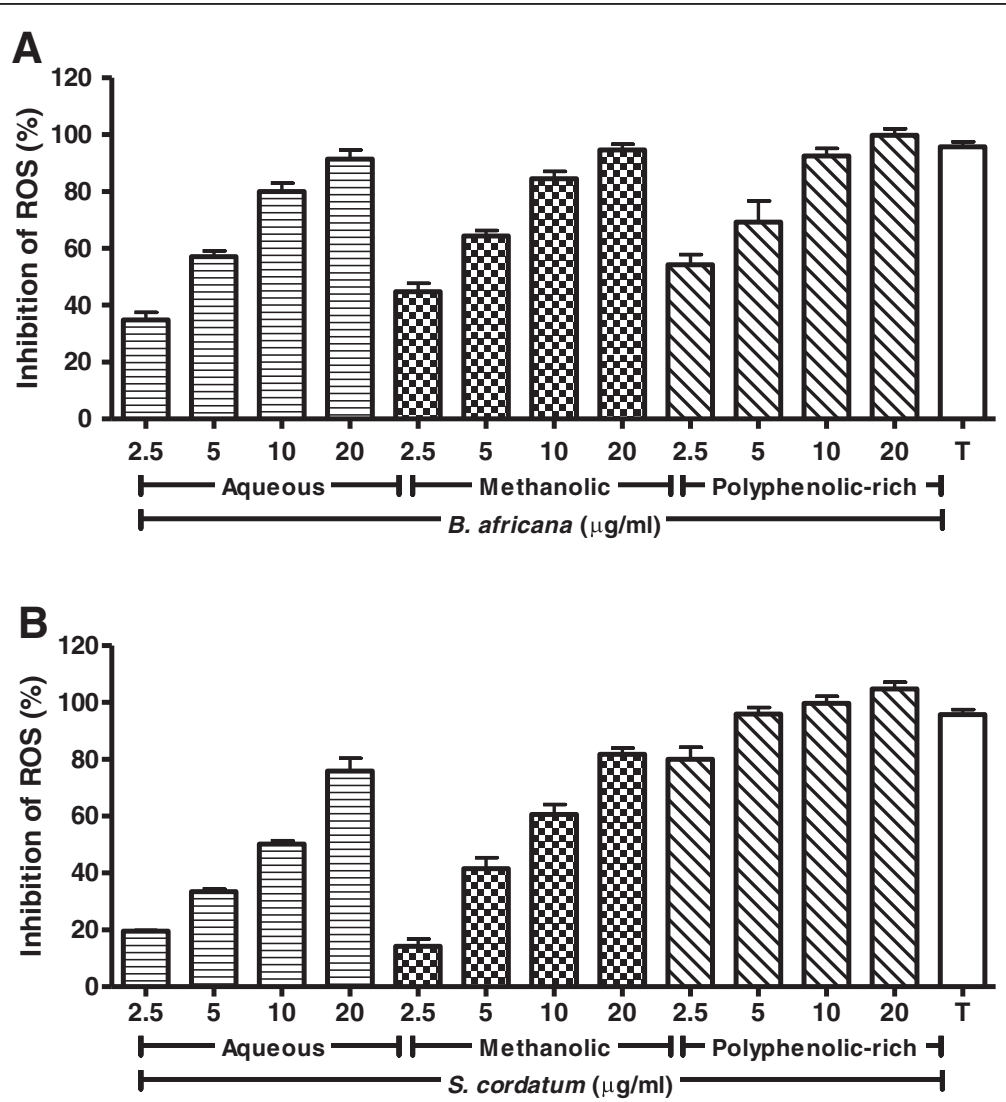

Figure 1 Inhibition of AAPH-induced ROS generation in U937 cells pre-treated with crude extracts and polyphenolic-rich fractions. Legend: A) B. africana and B) S. cordatum. 
free radical scavenging ability than this known commercial antioxidant supplement.

\section{Cytotoxicity of crude extracts and polyphenolic-rich fractions}

Literature could not be obtained for comparison with regards to cytotoxicity testing using the cell lines in the present study. Crude extracts and polyphenolic-rich fractions displayed cytotoxicity in the $\mathrm{C} 2 \mathrm{C} 12$ and 3T3L1 cell lines, but not in the U937 and NHDF cells (Table 2). The highest cytotoxicity was observed for the polyphenolic-rich fractions. The methanolic extract and polyphenolic-rich fraction of $B$. africana were more cytotoxic than the aqueous extract, whereas the methanolic extract of S. cordatum was less toxic than its aqueous extract. The $\mathrm{C} 2 \mathrm{C} 12$ cell line was more susceptible to the cytotoxicity induced by $B$. africana extracts than the 3T3-L1 cell line, while the inverse was observed with $S$. cordatum extracts.

In the present study, the cytotoxicity of the aqueous extract of B. africana $(84.5 \mu \mathrm{g} / \mathrm{ml})$ in 3T3-L1 cells was comparable to that described for an ethanolic stem extract using the brine shrimp toxicity assay $(87.24 \mu \mathrm{g} / \mathrm{ml})$. [29] The cytotoxicity noted for the crude extracts and polyphenolic-rich fraction of $S$. cordatum is comparable to that obtained for dichloromethane:methanol and acetone extracts using human kidney epithelial cells [30] and green monkey Vero cells [31], although the latter cells showed no toxicity to methanolic extracts [31,32].

Although the mechanism of action of cytotoxicity of the crude extracts and polyphenolic-rich fractions observed in the present study and in those reported in the literature is not known, indications are that polyphenols may produce cell death in the 3T3-L1 cells due to their inherent anti-adipogenic activity [33], by inducing cell cycle disturbances and initiation of apoptosis $[33,34]$.

\section{Attenuation of oxidative stress-induced parameters in U937 cells}

Protection against AAPH-induced ROS generation, lipid peroxidation, apoptosis and cytotoxicity

AAPH generated approximately 17 -fold higher levels of ROS than the negative control over a $3 \mathrm{~h}$ period. Pretreatment with crude extracts and polyphenolic-rich fractions for $1 \mathrm{~h}$ reduced this ROS generation (Figure 1 ). While crude extracts of $B$. africana had superior activity compared to that of $S$. cordatum, the polyphenolic-rich fraction of $S$. cordatum surpassed that of $B$. africana, resulting in $80 \%$ inhibition at $2.5 \mu \mathrm{g} / \mathrm{ml}$.
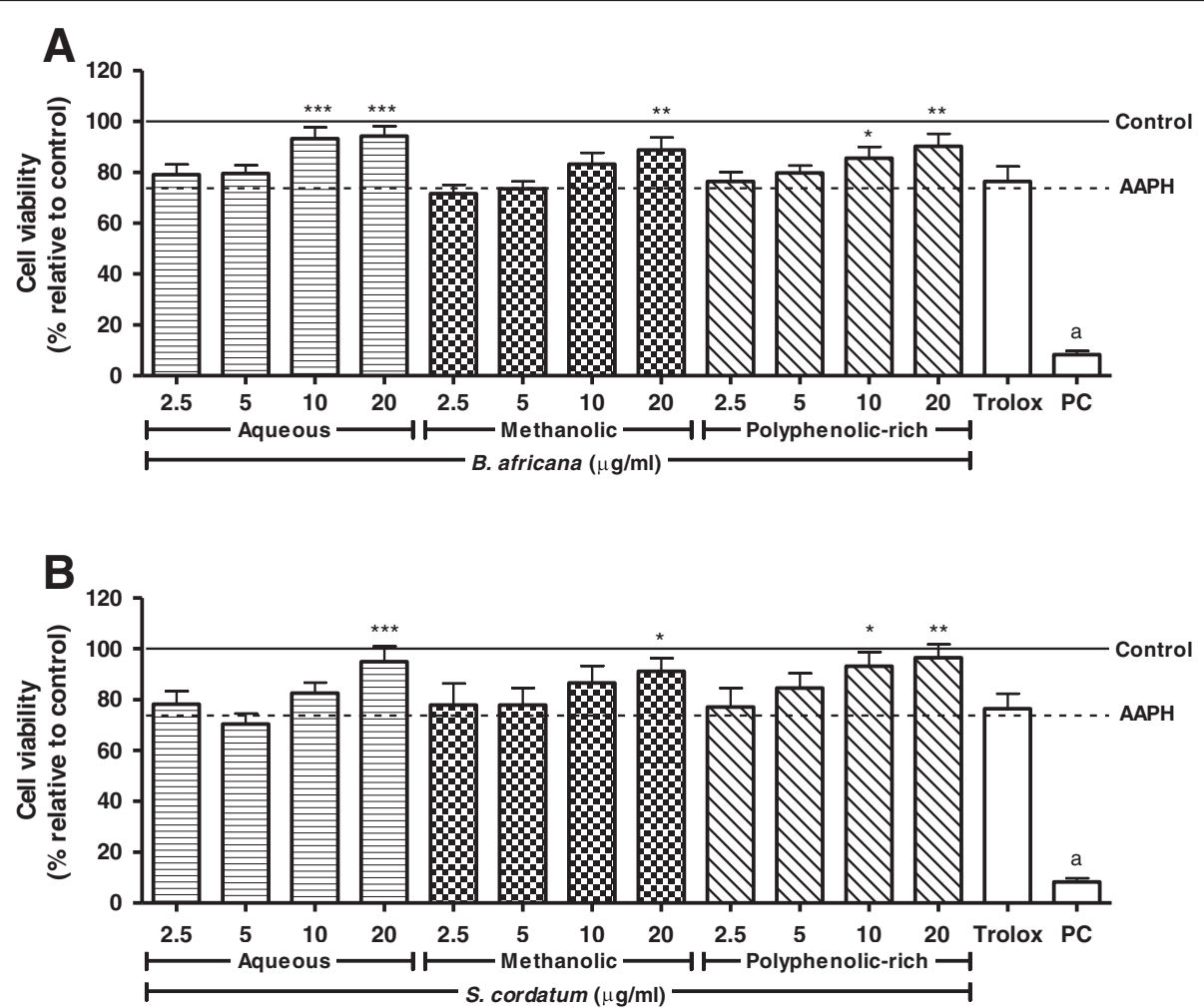

Figure 2 Protection against AAPH-induced cytotoxicity in U937 cells pre-treated with crude extracts and polyphenolic-rich fractions. Legend: A) B. africana and B) S. cordatum; PC = Positive control (saponin); solid and dashed lines represent negative control and AAPH-treated cells, respectively; control vs AAPH: $a-p<0.001$; AAPH vs sample: ${ }^{* *}-p<0.001,{ }^{* *}-p<0.01,{ }^{*}-p<0.05$. 
Cell viability was reduced to $73.68 \%$ after exposure to AAPH, but pre-treatment with crude extracts and polyphenolic-rich fractions (10 and $20 \mu \mathrm{g} / \mathrm{ml}$ ) of both plants increased survival of cells to above $80 \%$ (Figure 2). The polyphenolic-rich fraction of $S$. cordatum tended to protect the cells to a greater degree than $B$. africana but the difference in this protection was not significant.

Lipid peroxidation was induced after exposure to AAPH as measured by MDA formation (384.4\%) (Figure 3). Reduction of MDA concentrations was observed for both crude extracts and polyphenolic rich fractions of B. africana. However, only the polyphenolic-rich fraction of $S$. cordatum had a protective effect.

AAPH-exposure increased apoptosis as measured by caspase- 3 activity by $33.6 \%$ (Figure 4 ). While all samples of $B$. africana were able to decrease caspase- 3 activity, only the polyphenolic-rich fraction of $S$. cordatum elicited a definitive response. Apoptosis was decreased significantly $(p<0.05)$ in a dose-dependent manner by $B$. africana, with the polyphenolic-rich fraction being most potent, followed by the methanolic and aqueous extracts. The crude extracts of $S$. cordatum were less cytoprotective and did not follow a specific trend. All concentrations of the polyphenolic-rich fraction of $S$. cordatum decreased caspase-3 activity significantly $(p<0.05)$.
All samples of $B$. africana and the polyphenolic-rich fraction of $S$. cordatum resulted in protection against lipid peroxidation and apoptosis. A larger decrease in apoptosis was seen in the polyphenolic-rich fraction of $B$. africana than that of $S$. cordatum, even though the latter had greater antioxidant activity. This could suggest the presence of non-antioxidant phytochemicals contributing to the anti-apoptotic effect. The lack of effect seen with the crude extracts of $S$. cordatum could be attributed to the lower polyphenolic content and antioxidant activity of these crude extracts (as seen in the cell-free antioxidant assays). Furthermore, cytoprotection is dependent on the amount of phytochemicals that are able to move across the cell membrane [35]. The inhibition of lipid peroxidation decreases the formation of peroxidation by-products, which have been implicated in the induction of proapoptotic factors [36]. Thus apoptosis could be reduced through inhibition of lipid peroxidation. Additionally, apoptosis could be deterred through mitochondrial stabilization, deactivation of caspase cascades or reversal of ROS generation [37].

Hydroethanol extracts of $B$. africana were reported to decrease bovine phospholipid damage $\left(\mathrm{IC}_{50}=78 \mu \mathrm{g} / \mathrm{ml}\right)$ [7] and although no $\mathrm{IC}_{50}$ was obtained in the present study, a $43 \%$ inhibition of lipid peroxidation was seen for the
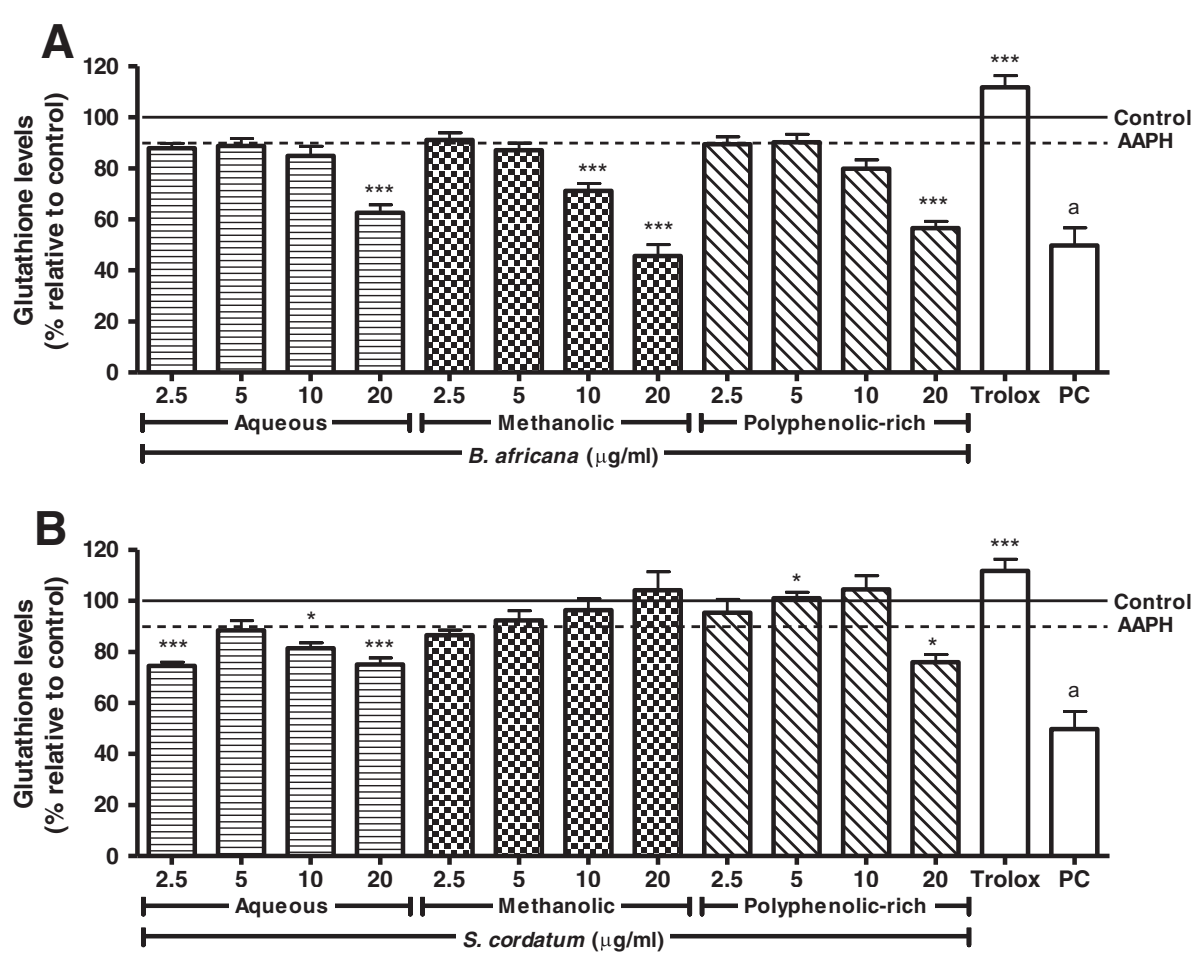

Figure 3 Inhibition of AAPH-induced lipid peroxidation in U937 cells pre-treated with crude extracts and polyphenolic-rich fractions. Legend: A) B. africana and B) S. cordatum; PC = Positive control $\left(\mathrm{H}_{2} \mathrm{O}_{2}\right)$; solid and dashed lines represent negative control and AAPH-treated cells, respectively; control vs AAPH: $a-p<0.001$; AAPH vs sample: ${ }^{* *}-p<0.001$, $^{* *}-p<0.01$, $^{*}-p<0.05$. 

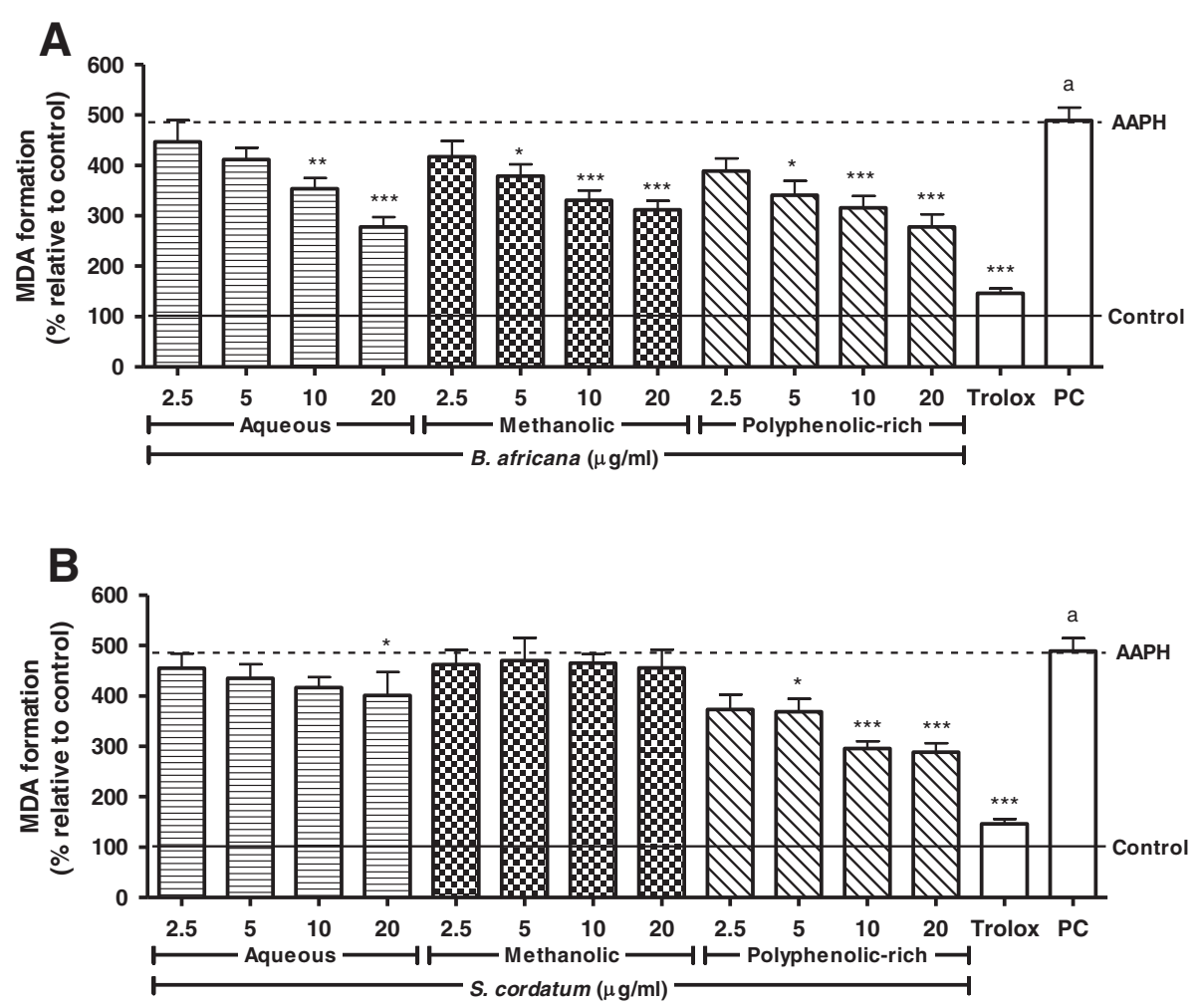

Figure 4 Inhibition of AAPH-induced caspase-3 activation in U937 cells pre-treated with crude extracts and polyphenolic-rich fractions. Legend: A) B. africana and B) S. cordatum; PC = Positive control (staurosporine); solid and dashed lines represent negative control and AAPHtreated cells, respectively; control vs AAPH: $a-p<0.001$; AAPH vs sample: ${ }^{* *}-p<0.001,{ }^{* *}-p<0.01,{ }^{*}-p<0.05$.

polyphenolic-rich fraction at $20 \mu \mathrm{g} / \mathrm{ml}$. Previously, reduced lipid peroxidation has been attributed to polyphenolic and anthocyanin content of Syzygium cumini Skeels [38].

The possibility exists that polyphenols that are present within both plants (as described in the literature or identified in the present study using TLC) may have contributed to the decrease in oxidative stress parameters assessed in U937 cells. This may include caffeic acid [39], catechin, epicatechin [40] and gallic acid [41]. Myricetin, which was identified in $B$. africana, has been shown to reduce 1-methyl-4-phenyl-1,2,3,6-tetrahydropyridin-induced ROS generation and cytotoxicity in MES23.5 rat dopaminergic cells [42]. This antioxidant has also been reported to reduce phosphorylation of MKK4 and JNK, neutralize free radicals (all of which reverse mitochondrial dysfunction), apoptosis and DNA damage [42]. Anthocyanins [43], similar to the anthocyanidins leucocyanidin and leucodelphinidin, and the triterpenoid, arjunolic acid [44], have been shown to reduce oxidative stress in vitro which can contribute to the cytoprotective effects seen with $S$. cordatum pre-treatment by decreasing apoptosis and lipid peroxidation. Studies carried out on individual polyphenols and phytochemicals identified in the plants studied, such as arjunolic acid, catechin, epicatechin, gallic acid, hesperidin and myricetin reported decreased lipid peroxidation [44-47] and apoptosis $[35,42,44,48,49]$ induced by oxidative stress. Isoflavones, present in most plants of the Fabaceae family, decrease oxidative-induced lipid damage through incorporation into low-density lipid particles [50], which might explain the reduction seen in all samples of B. africana. Procyanidins stabilize lipid membranes, which decreases the movement of ROS into the hydrophobic intracellular compartment and as such attenuates damage [51]. The most described mechanisms of reduced apoptosis were through the reduction in proapoptotic signals, upregulation of anti-apoptotic proteins and stabilization of the mitochondrial membrane. Ultimately cell viability was increased in all cells pre-treated with samples of both plants, indicating that different factors are at play which is decreasing the cytotoxicity induced by AAPH - including the induction of necrosis, DNA damage, inflammatory responses and mitochondrial dysfunction. These are typical parameters that should be targeted during treatment of oxidative stress-related disorders, and as such antioxidant supplementation from the bark of these plants could assist in limiting damage brought upon cells. 


\section{Protection against AAPH-induced GSH depletion}

APPH exposure reduced GSH concentrations by $10.24 \%$ (Figure 5). All samples of $B$. africana resulted in a decrease in GSH concentrations, with the methanolic extract being the most potent. The aqueous extract of $S$. cordatum reduced GSH whereas the methanolic extract increased GSH concentrations (as expected from antioxidant supplementation).

The crude extracts and polyphenolic-rich fractions of B. africana as well as the aqueous extract of S. cordatum decreased intracellular GSH concentrations dosedependently. Although studies support the increase of endogenous antioxidant stores brought about through antioxidant pre-treatment [52], this was not observed in the present study for B. africana.

Polyphenols such as flavonoids and catechins are reported to be able to decrease glutathione reductase activity [53], which in turn decreases the amount of GSH converted from GSSG. Furthermore, GSH-polyphenol complexes decrease the amount of GSH available to cells, by increasing GSSG/GSH ratio and ultimately being released extracellularly. Such conjugations can form from polyphenol o-quinone metabolites [54]. Although GSH depletion was noted, other antioxidant systems such as superoxide dismutase and catalase could have been affected and thus led to an increase in protection. Although the cells were essentially susceptible to oxidative attack due to decreased endogenous GSH, cell viability was not affected. The reduction of ROS brought on by pre-treatment with crude extracts and polyphenolic-rich fractions is thought to decrease the amount of free radicals available to damage cells. This however does not fully explain the protection in the absence of GSH, therefore stabilization of other parameters should be considered, such as decreased apoptotic factors and protection against lipid peroxidation.

\section{Conclusion}

Although literature concerning B. africana and S. cordatum is limited, the bark of both of these plants is known to contain a variety of polyphenols, which justifies its potential use as an antioxidant supplement for oxidative stress-related disorders. Cytotoxic parameters such as cytotoxicity, ROS generation, lipid peroxidation and apoptosis were decreased by extracts from both plants studied. The highest activity was noted for the polyphenolic-rich fractions, which can largely be attributed to their higher polyphenolic content and antioxidant activities. Although reduction of oxidative stress-related parameters were observed, cytotoxicity
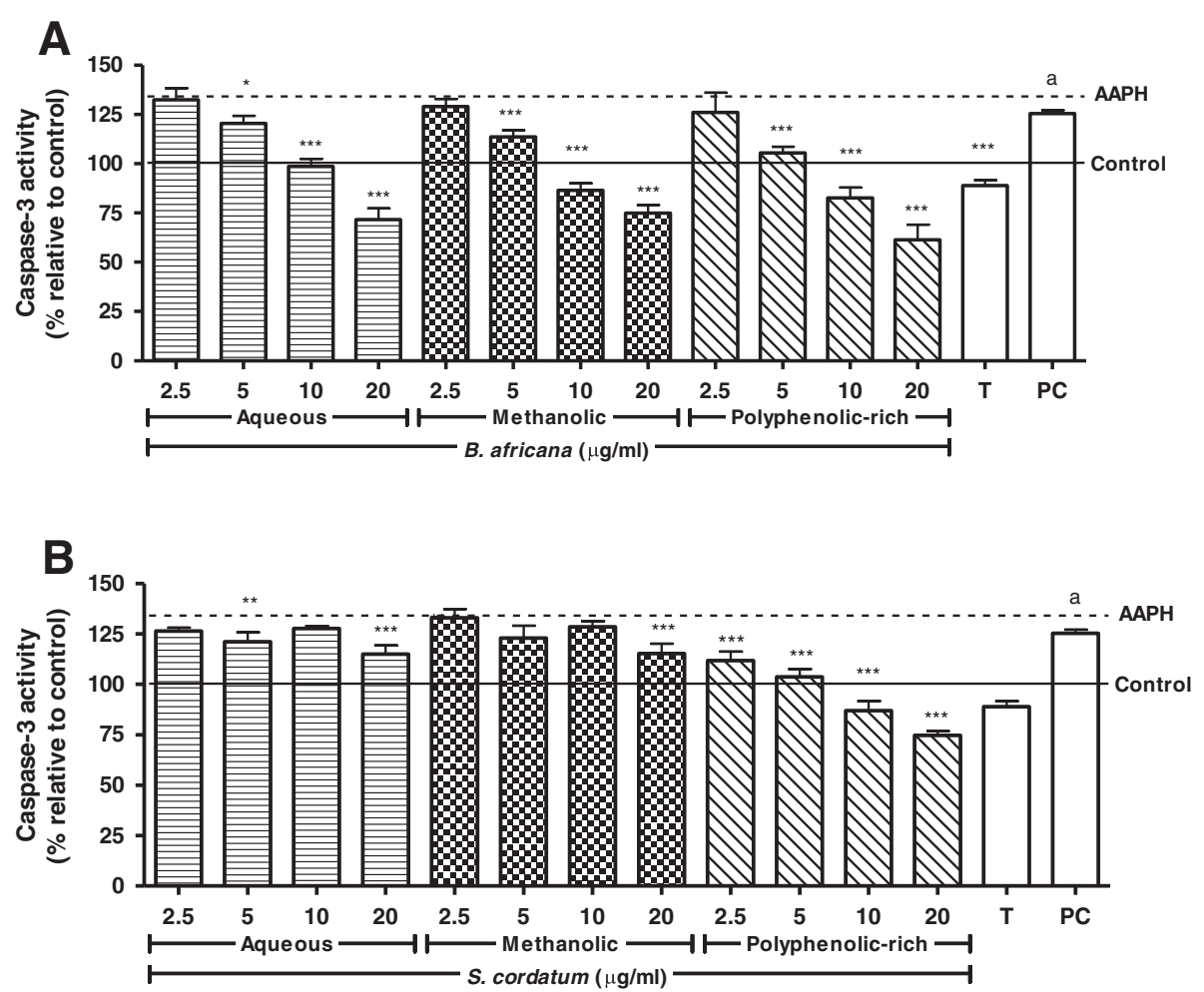

Figure 5 Effect on AAPH-induced glutathione depletion in U937 cells pre-treated with crude extracts and polyphenolic-rich fractions. Legend: A) B. africana and B) S. cordatum; PC = Positive control $\left(\mathrm{H}_{2} \mathrm{O}_{2}\right)$; solid and dashed lines represent negative control and AAPH-treated cells, respectively; control vs AAPH: $a-p<0.001$; AAPH vs sample: *** $-p<0.001,{ }^{*}-p<0.05$. 
was induced by extracts from both plants in the cultured 3T3-L1 and $\mathrm{C} 2 \mathrm{C} 12$ cell lines. This could result in difficulties in development of an antioxidant supplementation. Further isolation and purification of polyphenolic-rich fractions could lead to identification and elimination of cytotoxic elements, while maintaining antioxidant potential. Such refinement could increase the potential of the polyphenolic-rich fraction to be used as a health-supplement.

\section{Competing interests}

The authors declared that they have no competing interest.

\section{Authors' contributions}

WC conducted all experiments and drafted the manuscript. MG, ADC and VS provided critical appraisal of technical work and the manuscript. All authors read and approved the final manuscript.

\section{Acknowledgements}

The authors wish to acknowledge the National Research Foundation for funding.

\section{Author details}

'Department of Pharmacology, Faculty of Health Sciences, School of Medicine, University of Pretoria, P.O. Box X323, Arcadia 0007, Pretoria, South Africa. ${ }^{2}$ Toxicology and Biochemistry Section, National Institute for Occupational Health, Johannesburg, South Africa. ${ }^{3}$ Department of Haematology and Molecular Medicine, Faculty of Health Sciences, University of Witwatersrand, Johannesburg, South Africa.

Received: 21 February 2013 Accepted: 22 May 2013

Published: 28 May 2013

\section{References}

1. Farber JL: Mechanisms of cell injury by activated oxygen species. Environ Health Perspect 1994, 102:17-24.

2. Irshad M, Chaudhuri PS: Oxidant-antioxidant system: role and significance in human body. Indian J Exp Biol 2002, 40:1233-1239.

3. Pérez VI, Bokov A, van Remmen H, Mele J, Ran Q, Ikeno Y, Richardson A: Is the oxidative stress theory of aging dead? Biochim Biophys Acta 2009, 1790:1005-1114

4. Zeraik ML, Serteyn D, Deby-Dupont G, Wauters J-N, Tits M, Yariwake JH, Angenot L, Franck T: Evaulation of the antioxidant acitivity of passion fruit (Passiflora edulis and Passiflora alata) extracts on stimulated neutrophils and myeloperoxidase activity assays. Food Chem 2011, 128:259-265.

5. Rahman I, Adcock IM: Oxidative stress and redox regulation of lung inflammation in COPD. Eur Respir J 2006, 28:219-242.

6. Mariod AA, Ibrahim RM, Ismail M, Ismail N: Antioxidant activities of phenolic rich fractions (PRFs) obtained from black mahlab (Monechma ciliatum) and white mahlab (Prunus mahaleb) seedcakes. Food Chem 2010, 118:120-127.

7. Mathisen E, Diallo D, Anderson ØM, Malterud KE: Antioxidants from the bark of Burkea africana, and African medicinal plant. Phytother Res 2002, 16:148-153.

8. van Wyk B-E, Gericke N: People's Plants - A Guide to Useful Plants of Southern Africa. South Africa: Briza Publications; 2000.

9. Jung MY, Jeon BS, Bock JY: Free, esterified and insoluble bound phenolic acids in white and red ginsengs (Panax ginseng C.A. Meyer). Food Chem 2002, 79:105-111.

10. Harborne JB: Phytochemical methods - a guide to modern techniques of plant analysis. Great Britain: Chapman \& Hall; 1973.

11. Siddiqui AA, Ali M: Practical pharmaceutical chemistry $1^{\text {st }}$ edition. New Delhi: CBS Publishers and Distributers; 1997:126-131.

12. Slinkard $\mathrm{K}$, Singleton VL: Total phenol analysis: automation and comparison with manual methods. Am J Enol Vitic 1977, 28:49-55.

13. Dewanto V, Wu X, Adom KK, Liu RH: Thermal processing enhances the nutritional value of tomatoes by increasing total antioxidant activity. J Agric Food Chem 2002, 50:3010-3014.
14. Re R, Pellegrini N, Proteggente A, Pannala A, Yang M, Rice-Evans C: Antioxidant activity applying an improved $A B T S$ radical cation decolorization assay. Free Radic Biol Med 1999, 26:1231-1237.

15. Gyamfi MA, Yonamine $M$, Aniya Y: Free-radical scavenging action of medicinal herbs from Ghana. Thonningia sanguinea on experimentallyinduced liver injuries. Gen Pharmacol 1999, 32:661-667.

16. Borenfreund E, Babich H, Martin-Alguacil A: Rapid chemosensitivity assay with human normal and tumor cells in vitro. In Vitro Cell Dev Biol 1990, 26:1030-1034

17. Pinchuk I, Lichtenberg D: The mechanism of action of antioxidants against lipoprotein peroxidation, evaluation based on kinetic experiments. Prog Lipid Res 2002, 41:279-314.

18. Pedriali CA, Fernandes AU, Bernusso LDC, Polakiewiz B: The synthesis of a watersoluble derivative of rutin as an antiradical agent. Quim Nova 2008, 31:2147-2151.

19. Jakubowski W, Bartosz G: 2,7-dichlorofluorescein oxidation and reactive oxygen species: What does it measure? Cell Biol Int 2000, 24:757-760.

20. Banjerdpongchai $R$, Kongtawelert $P$, Khantamat $O$, Srisomsap $C$, Chokchaichamnankit D, Subhasitanont P, Svasti J: Mitochondrial and endoplasmic reticulum stress pathways cooperate in zearalenoneinduced apoptosis of human leukemic cells. J Hematol Oncol 2010, 3:50.

21. Stern ST, Potter TM, Neun BW: NCL method GTA-4; Hep G2 hepatocyte lipid peroxidation assay. Nanotechnology Characterization Laboratory, National Cancer Institute-Frederick; 2010

22. Fernandez-Checa JC, Kaplowitz N: The use of monochlorobimane to determine hepatic GSH levels and synthesis. Anal Biochem 1990, 190:212-219.

23. Diallo D, Marston A, Terreaux C, Touré Y, Smestad Paulsen B, Hostettman K: Screening of Malian medicinal plants for fungicidal, larvicidal, molluscicidal, antioxidant and radical scavenging activities. Phytother Res 2001, 15:401-406.

24. Tanko Y, lliya B, Mohammed A, Mahdi MA, Musa KY: Modulatory effect of the stem bark extract of Burkea africana on castrol oil induced diarrhoeal on experimental animals. Arch App/ Sci Res 2011, 3:122-130.

25. Candy HA, McGarry EJ, Pegel KH: Constituents of Syzygium cordatum. Phytochemistry 1968, 7:889-890

26. Hutchings A, Scott AH, Lewis G, Cunningham AB: Zulu Medicinal Plants-An Inventory. Petermaritzburg: University of Natal Press; 1996:118-119.

27. Pallant CA, Steenkamp V: In-vitro bioactivity of Venda medicinal plants used in the treatment of respiratory conditions. Hum Exp Toxicol 2008, 27:859-866.

28. de Beer D, Joubert E, Gelderblom WCA, Manley M: Antioxidant activity of South African red and white cultivar wines: free radical scavenging. J Agric Food Chem 2003, 51:902-909.

29. Moshi MJ, Mbwambo ZH, Nondo RSO, Masimba PJ, Kamuhabwa A, Kapingu MC, Thomas P, Richard M: Evaluation of ethnomedicinal claims and brine shrimp toxicity of some plants used in Tanzania as traditional medicines. Afr J Trad CAM 2006, 3:48-58.

30. Sibandze GF, van Zyl RL, van Vuuren SF: The anti-diarrhoeal properties of Breonadia salicana, Syzygium cordatum and Ozoroa sphaerocarpa when used in combination in Swazi traditional medicine. J Ethnopharmacol 2010, 132:506-511.

31. Samie A, Obi CL, Lall N, Meyer JJM: In-vitro cytotoxicity and antimicrobial activities, against clinical isolates of Campylobacter species and Entamoeba histolytica, of local medicinal plants from the Venda region, in South Africa. Ann Trop Med Parisitol 2009, 103:159-170.

32. Mativandlela SPN, Meyer JJM, Hussein AA, Houghton PJ, Hamilton CJ, Lall N: Activity against Mycobacterium smegmatis and $M$. tuberculosis by extract of South African medicinal plants. Phytother Res 2008, 22:841-845.

33. Hung P-F, Wu B-T, Chen H-C, Chen Y-H, Chen C-L, Wu M-H, Liu H-C, Lee M-J, Kao Y-H: Antimitogenic effect of green tea (-)-epigallocatechin gallate on 3T3-L1 preadipocytes depends on the ERK and Cdk2 pathways. Am J Physiol Cell Physiol 2005, 288:C1094-C1108.

34. Hsu C-L, Lo W-H, Yen G-C: Gallic acid induces apoptosis in 3T3-L1 preadipocytes via a Fas- and mitochondrial-mediated pathway. J Agric Food Chem 2007, 55:7359-7365.

35. Hwang $S-L$, Yen G-C: Neuroprotective effects of citrus flavanones against $\mathrm{H}_{2} \mathrm{O}_{2}$-induced cytotoxicity in PC12 cells. J Agric Food Chem 2008, 56:859-864.

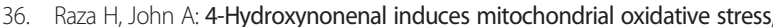
apoptosis and expression of glutathione S-transferase A4-4 and cytochrome P450 2E1 in PC12 cells. Toxicol Appl Pharmacol 2006, 216:309-318.

37. Harwood SM, Yaqoob MM, Allen DA: Caspase and calpain function in cell death: bridging the gap between apoptosis and necrosis. Ann Clin Biochem 2005, 42:415-431. 
38. Veigas JM, Narayan MS, Laxman PM, Neelwarne B: Chemical nature, stability and bioefficacies of anthocyanins from fruit peel of Syzygium cumini Skeels. Food Chem 2007, 105:619-627.

39. Froemming GR, O'Brien NM: U937 cells as a model to study the effect of phytochemicals on superoxide anion production. Nutr Res 1997, 17:1091-1103.

40. Kanupriya P, Dipti P, Sharma SK, Sairam M, llavazhagan G, Sawhney RC, Banerjee PK: Flavonoids protect U-937 macrophages against tertbutylhydroperoxide induced oxidative injury. Food Chem Toxicol 2006, 44:1024-1030

41. Charoenteeraboon J, Ngamkitidechakul C, Soonthornchareonnon N, Jaijoy K, Sireeratawong S: Antioxidant activities of the standardized water extract from fruit of Phyllanthus emblica Linn. I Sci Technol 2010, 32:599-604.

42. Zhang K, Ma Z, Wang J, Xie A, Xie J: Myricetin attenuated MPP ${ }^{+}$-induced cytotoxicity by anti-oxidation and inhibition of MKK 4 and JNK activation in MES23.5 cells. Neuropharmacology 2011, 61:329-335.

43. Youdim KA, Martin A, Joseph JA: Incorporation of the elderberry anthocyanins by endothelial cells increases against oxidative stress. Free Radic Biol Med 2000, 29:51-60.

44. Pal S, Pal PB, Das J, Sil PC: Involvement of both intrinsic and extrinsic pathways in hepatoprotection of arjunolic acid against cadmium induced acute damage in vitro. Toxicology 2011, 283:129-239.

45. Koleckar V, Kubikova K, Rehakova Z, Kuca K, Jun D, Jahodar L, Opletal L: Condensed and hydrolysable tannins as antioxidants influencing the health. Mini Rev Med Chem 2008, 8:436-447.

46. Chen M, Gu H, Ye Y, Lin B, Sun L, Deng W, Zhang J, Liu J: Protective effects of hesperidin against oxidative stress of tert-butylhydroperoxide in human hepatocytes. Food Chem Toxicol 2010, 48:2980-2987.

47. Souček P, Kondrová E, Heŕmánek J, Stopka P, Boumendjel A, Ueng Y-F, Gut I: New model system for testing effects of flavonoids on doxorubicinrelated formation of hydroxyl radicals. Anticancer Drugs 2011, 22:176-184.

48. Du Y, Lou H: Catechin and proanthocyanidin B4 from grape seeds prevent doxorubicin-induced toxicity in cardiomyocytes. Eur J Pharmacol 2008, 591:96-101.

49. Yu J, Xu Y, Khaoustov V, Yoffe B: Identification of components of grape powder with anti-apoptotic effects. Toxicol Ind Health 2011, 27:19-28

50. Tikkanen MJ, Adlercreutz H: Dietary soy-derived isoflavone phytoestrogens: could they have a role in coronary heart disease prevention? Biochem Pharmacol 2000, 60:1-5.

51. Verstraeten SV, Hammerstone JF, Keen CL, Fraga CG, Oteiza PI: Antioxidant and membrane effects of procyanidin dimers and trimers isolated from peanut and cocoa. J Agric Food Chem 2005, 53:5041-5048.

52. Yu D, Duan $Y, B a o$ Y, Wei $C$, An L: Isoflavonoids from Astragalus mongholicus protect $\mathrm{PC} 12$ cells from toxicity induced by L-glutamate. J Ethnopharmacol 2005, 98:89-94

53. Zhang K, Yan E-B, Tang W-Y, Wong KP, Mack P: Inhibition of glutathione reductase by plant polyphenols. Biochem Pharmacol 1997, 54:1047-1053.

54. Galati G, Sabzevari O, Wilson JX, O'Brien PJ: Prooxidant activity and cellular effects of the phenoxyl radicals of dietary flavonoids and other polyphenolics. Toxicology 2002, 177:91-104.

doi:10.1186/1472-6882-13-116

Cite this article as: Cordier et al: Attenuation of oxidative stress in U937 cells by polyphenolic-rich bark fractions of Burkea africana and Syzygium cordatum. BMC Complementary and Alternative Medicine 2013 13:116.

\section{Submit your next manuscript to BioMed Central and take full advantage of:}

- Convenient online submission

- Thorough peer review

- No space constraints or color figure charges

- Immediate publication on acceptance

- Inclusion in PubMed, CAS, Scopus and Google Scholar

- Research which is freely available for redistribution 